\title{
Biochemical and behavioral responses in carp fish exposed to tricaine methane sulfonate (MS-222) as anesthetic drug under transport conditions
}

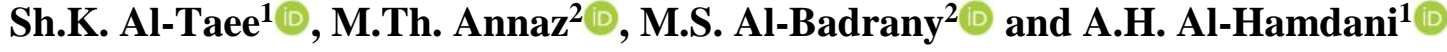 \\ ${ }^{1}$ Department of Pathology and Poultry Diseases, ${ }^{2}$ Department of Veterinary surgery and Theriogenology, College of \\ Veterinary Medicine, University of Mosul, Mosul, Iraq
}

\begin{tabular}{l} 
Article information \\
\hline Article history: \\
Received August 15, 2020 \\
Accepted December 13, 2020 \\
Available online October 1,2021 \\
\hline Keywords: \\
Anesthetic drug \\
Stress \\
Fish transportation \\
Enzymatic study \\
Hematological study \\
\hline Correspondence: \\
M.S. Al-Badrany \\
muneert16@yahoo.com
\end{tabular}

\begin{abstract}
This study aims to determine the effects of Tricaine methane-sulfonate (MS-222) at concentration $150 \mathrm{mg} / \mathrm{l}$ for one hour as an anesthetic agent to reduce the stress conditions during transfer the fish. Forty fish (Cyprinus carpio) were divide in to four groups: the $1^{\text {st }}$ is control group (fish without both transfer and anesthesia), the $2^{\text {nd }}$ group (fish transfer without anesthesia), the $3^{\text {rd }}$ group (fish anesthesia without transfer) and the $4^{\text {th }}$ group (fish transfer with anesthesia). The induction time reached to 3 minutes while the recovery time take at lasted for 7 to 10 minutes. Furthermore, the cortisol was significantly decreased in fish serum in both anesthetized groups that were transferred or that were left in the pond without transmission in compare to control groups (both transfer and without transfer fish). The glucose level rose significantly $(\mathrm{P}<0.05)$ in the serum of fish in both $3^{\text {rd }}$ and $4^{\text {th }}$ groups in compare to control groups. There was no difference in hematological parameters (hemoglobin and packed cell volume), blood sodium ion concentration, and enzyme activity represented by alanine amino transferase in all groups while level of creatinine phosphate was decrease significantly in both groups $2^{\text {nd }}$ and $3^{\text {ed }}$ in compare to $1^{\text {st }}$ group. It can be concluded that tricaine methane-sulfonate stimulates the recovery and shortens the time of induction and reduces the stress condition caused by fish transport.
\end{abstract}

DOI: 10.33899/ijvs.2020.128035.1552, (CAuthors, 2021, College of Veterinary Medicine, University of Mosul.

This is an open access article under the CC BY 4.0 license (http://creativecommons.org/licenses/by/4.0/).

\section{Introduction}

Fish in wild and captive environments are exposed to stressful conditions, which are defined as groups of various factors that affect fish and are unable to maintain normal physiological status (1). Stress in fish can be caused by biological causes such as microorganisms or their toxins, changes in the physicochemical properties of the water environment, and physical causes such as fishing, overgrowth, and nets, which arise the stress during fish transport (2-4). Many stress factors are associated with the transport of fish like poor water quality, reservoir identification, and handling. Stress responses can be primary responses to blood release hormones and the circulatory system that lead to secondary responses, including gill blood flow (ionic osmotic disorders), metabolic rate and heart rate (5). Various methods have been used to reduce stress and mortality during transportation by pumping air, adding ice and liquefied oxygen, non-toxic salt, or a low concentration of calcium chloride (6). Anesthesia is an essential method in aquaculture that is used to relieve stress during the handling and transportation of fish. This anesthetic drug is characterized by rapid induction and recovery; it is also not toxic for fish or human's consumption $(7,8)$. Tricaine methane-sulfonate (MS-222) is a benzocaine derivative, a white crystalline powder that dissolves in water. It can be in the form of a powder or a liquid; it is unstable under direct light, and it should be stored in dark solutions. It is absorbed through the gills and skin and then biologically converted into the liver, kidneys, and gills and its metabolites were 
excreted in the urine and bile, it take 21 day for withdrawal from fish body $(9,10)$. The MS-222 concentration ranges from 15 to $330 \mathrm{mg} / \mathrm{l}$. many factors affect the difference and the effectiveness of MS-222. The most important factor is water temperature, a higher temperatures mean higher efficiency (with regards to induction and recovery time) for MS-222 (11). Moreover, small fish are more sensitive to MS222 than larger fish, in general it may have related to high metabolic activity than large fish. A lower concentration is also more effective in anesthesia (12). The physiological state of the fish as maturity, age, sex and fish species play a role in the effectiveness of MS-222 (13). Moreover, the anesthetic concentration varies depending on the the alkalinity of water, $\mathrm{pH}$, hardness, and seasonality (14). For instance, some studies show the effects of MS-222 stress by increasing cortisol release in fish and leukopenia; there may be an increase in the concentration of hemoglobin and abnormal erythrocytes in Cyprinus carpio (15-17).

The present study aims to determine the time of induction and recovery in anesthetized fish using MS-222 to assess changes in hormonal, biochemical, and hematological factors with ion concentration in fish serum.

\section{Materials and methods}

Fish (Cyprinus carpio) (18) were collected from one of the commercial fishponds. The average weight of fish was $125 \pm 10 \mathrm{~g}$. The fish were kept in a cement tank to ensure regular freshwater supply, and they were fed with commercial pellets for seven days. The fish were starved for 24 hours before the experiment and placed in the aquarium two hours before the experiment.

Forty fish were divided into four groups, each group included ten fish that were placed in a glass aquarium with $40 * 40 * 30 \mathrm{~cm}$ dimensions. The first group was considered a control group fish left in the water without any treatment. The second group underwent a one-hour transfer and was considered a positive control group, while the third group received MS-222 $150 \mathrm{mg} / \mathrm{l}$ (19) for one hour and was left in the aquarium. The fourth group received MS-222 and was subjected to a one-hour transfer. The induction time and anesthesia stage were determined according to behavioral responses such as respiratory rate, abnormal swimming, and fish interaction with muscle tension and swing depended in table 1 (20). Fish were transported to freshwater without MS222 to determine the healing time.

A blood sample was drawn from a caudal vein from the fish in the four groups one hour after treatment and transport for biochemical tests (Cortisol, Glucose, Alanine aminotransferase ALT, Creatinine phosphate and sodium ion concentration) usage spectrophotometers method and blood study (Hb concentration and PCV).

\section{Statistical Analysis}

CRD-based design experiment and Duncan test were used to determine the relevance among treatments, SAS statistical programs, 2002.

Table 1: Stage of anesthesia in Cyprinus carpio exposure to MS-222 $150 \mathrm{mg} / \mathrm{l}$ for one hour

\begin{tabular}{lll}
\hline Stage & Description & Behavior Signs \\
\hline A0 & Normal & Active swimming, normal equilibrium, normal muscle tone to external stimuli \\
A1 & Light sedation & Reduced swimming, slight loss reactivity to visual and tactile stimuli and reduced respiratory rate \\
A2 & Light narcosis & Slight loss in equilibrium \\
A3 & Deep narcosis & Loss in equilibrium decreased muscle tone \\
\hline
\end{tabular}

\section{Results}

The results showed that using tricaine methane-sulfonate for fish $150 \mathrm{mg} / \mathrm{liter}$ as anesthetic dosage for one hour at a low respiratory rate of the fish resulted in a reduction in the frequency of opening the gills in both anesthetized groups of fish that underwent and did not undergo transportation. The study calculated the anesthesia time, which was 1 to 7 minutes and started at zero since the fish were swimming well and had normal muscle tension. The fish showed a low breathing frequency with a lack of response to external influences and slow swimming with loss of balance, muscle relaxation, and tail swaying with stability on the bottom after one minute of the starting drug effect (Table 1).

At the end of the test period, the fish were transferred to anesthetic-free water to calculate the wake-up time, which was 7 to 10 minutes, since after one minute the fish showed a slow movement of the gill lids, and after two minutes the fish started to swim slowly. It took some time to return to swim at a normal rate. A roll-up time of 3 to 5 minutes was observed. The fish swim normally and balanced after seven to ten minutes as shown in (Table 2). The serum cortisol concentration level in fish was significantly clear in both groups treated with the drug with transport and without transport (498.88 and 547.60) $\mathrm{mg} / \mathrm{ml}$ compare to the control group. The results of the present study refer to the first clinical signs. There was a decrease in respiratory rate (opercula frequency OF) in both anesthetized groups the transported and non-transported. The MS-222 with $150 \mathrm{mg} / \mathrm{l}$ took 1-7 min to get in the system of the fish and exhibit variable character for anesthetic stages beginning by normal behavior to the surgical stage. The MS-222 took the fish about 7 minutes to lose sensation and sink to the bottom of the aquarium (Table 2). The time of the experiment was one hour, so after these time fish were transported to freshwater and the time and stages of fish recovery were determined. 
The time begins with R1 characterize by return slow movement of opercula at $1 \mathrm{~min}$ and in $\mathrm{R} 2$ slow swimming at $2 \mathrm{~min}$, partial recovery of equilibrium at R3 at 3-5 min until fish appear to be normal swimming at 7-10 min (Table 2). The study results showed that there is a significant decline in serum cortisol concentration in both groups of anesthetized fish with and without transportation. The cortisol level reached to $498.88 \mathrm{mg} / \mathrm{ml}$ and $547.60 \mathrm{mg} / \mathrm{ml}$ in 1-hour compare to both control groups. The serum glucose levels in anesthetized fish that were transferred reached to 211.07 $\mathrm{mg} / \mathrm{ml}$ and $192.80 \mathrm{mg} / \mathrm{ml}$ in not transferred anesthetized fish. There is no variation between them. However, both were significantly elevated as compared to the positive control group as shown in (Table 3).

The biochemical result revealed that there were no effects of MS-222 on the concentration of ALT on all groups. Additionally, the concentration of creatinine phoshpate enzyme in the serum of anesthetized and transferred fish with MS-222 for 1 hour does not vary from other groups with statistical variation between all groups. Furthermore, there were no effects of MS-222 on both hematological parameters represented by $\mathrm{Hb}$ concentration and PCV and sodium ion concentration in the serum in all groups as can be seen in (Table 3).

Table 2: Stages of recovery

\begin{tabular}{lll}
\hline Stage & Behavior signs & Time \\
\hline R1 & Reappearance of the opercula movement & $1 \mathrm{~min}$ \\
R2 & Reappearance of slow swimming activity, loss equilibrium & $2 \mathrm{~min}$ \\
R3 & Abnormal swimming, Partial recovery of equilibrium, weak muscle tone but loss tail stimuli & $3-5 \mathrm{~min}$ \\
R4 & Reappearance of equilibrium, response to visual and tactile stimuli, still abnormal response & $7 \mathrm{~min}$ \\
R5 & Normal swimming activity and normal behavior activity & $7-10 \mathrm{~min}$ \\
\hline
\end{tabular}

Table 3: Effects of MS-222 on Biochemical and hematologic parameters and sodium-ion concentrations in fish

\begin{tabular}{lcccc}
\hline \multirow{2}{*}{ Parameters } & \multicolumn{2}{c}{ Control (Mean \pm Std.) } & \multicolumn{2}{c}{ Anesthesia (Mean \pm Std.) } \\
\cline { 2 - 5 } & Control & with transported & without transported & with transported \\
\hline Cortisol $(\mathrm{g} / \mathrm{ml})$ & $719.18 \pm 50.36 \mathrm{a}$ & $726.04 \pm 49.17 \mathrm{a}$ & $547.60 \pm 49.73 \mathrm{~b}$ & $498.88 \pm 38.21 \mathrm{~b}$ \\
Glucose $(\mathrm{mg} / \mathrm{l})$ & $140.14 \pm 21.44 \mathrm{ab}$ & $104.00 \pm 8.70 \mathrm{~b}$ & $192.80 \pm 21.06 \mathrm{a}$ & $211.07 \pm 31.23 \mathrm{a}$ \\
ALT $(\mathrm{U} / \mathrm{L})$ & $45.54 \pm 6.60 \mathrm{a}$ & $53.98 \pm 12.69 \mathrm{a}$ & $52.15 \pm 13.69 \mathrm{a}$ & $49.83 \pm 2.48 \mathrm{a}$ \\
$\mathrm{CK}(\mathrm{U} / \mathrm{L})$ & $1.30 \pm 0.16 \mathrm{a}$ & $0.46 \pm 0.14 \mathrm{~b}$ & $0.52 \pm 0.11 \mathrm{~b}$ & $0.88 \pm 0.18 \mathrm{ab}$ \\
$\mathrm{Na}(\mathrm{mmol} / \mathrm{l})$ & $36.97 \pm 10.71 \mathrm{a}$ & $22.02 \pm 5.50 \mathrm{a}$ & $32.33 \pm 11.90 \mathrm{a}$ & $65.96 \pm 22.92 \mathrm{a}$ \\
$\mathrm{Hb}(\mathrm{g} / \mathrm{dl})$ & $12.20 \pm 0.47 \mathrm{a}$ & $13.08 \pm 0.58 \mathrm{a}$ & $13.98 \pm 1.11 \mathrm{a}$ & $13.51 \pm 0.78 \mathrm{a}$ \\
$\mathrm{PCV}(\%)$ & $38.29 \pm 1.27 \mathrm{a}$ & $37.20 \pm \mathrm{a} 1.71$ & $38.60 \pm 2.11 \mathrm{a}$ & $39.81 \pm 1.24 \mathrm{a}$ \\
\hline
\end{tabular}

Varied letters mean there is a significant variation at $\mathrm{P}<0.05$.

\section{Discussion}

Fish exposed to various stressors that cause negative effects on fish performance and survival. According to Griffiths, the most important causes of stress include size, weighting, overcrowding, disturbances of water quality, and fish transportation (21). Moreover, stress causes physiological injuries, immunosuppressant's, and death (22). According to the type of stress variable methods have been used in aquaculture to reduce stress as food additive probiotic (23), anesthetic methods, decrease overcrowding and keep the water quantity and quality. The effective concentration of MS-222 was $150 \mathrm{mg} / \mathrm{l}$. The induction and recovery were shorter and lasted for 7 minutes. These results agree with the results of Park et al. (24) who mentioned the optimum anesthetic concentration. The anesthesia should be induced with 3 minutes with recovery occurring within 19 minutes (24). When the fish transported to clean water the recovery began at $1-2$ minutes characterized by slow movement of opercula and then returned to normal swimming after $7-10$ minutes. According to Kiessling, these rapid recoveries are attributed to the rapid elimination of MS-222 (25), which is not different from what we found in our results.

Tricaine induced aversive behavioral responses. These results are parallel to the results of Readman et al. (26) in that the anesthetic stages in Cyprinus carpio begin at the decline of opercula movement and loss of balance at a later stage, and fish settle at the bottom of the aquarium. All these anesthetic stages require 3 minutes. These results agree with the result of Park et al. (24). The characteristics of these stages of anesthesia may be related to the rapid absorption of MS-222 through the gills which inhibit the neural signal transmission from the periphery to the central nervous system (27).

During stress conditions, the neuroendocrine system is stimulated so there is an initial response characterized by the release of corticosteroid, which affects other physiological and some biochemical parameters such as glucose, hemoglobin, hematocrit, and enzyme activity (28). The cortisol level is a well-established indicator to fish stress response, and in our result, there was a significant elevation 
of cortisol in the fish serum in the control group that underwent the transportation to clean water. Stress hormones increase cardiac output and ventilation leading to an increase in bronchial blood flow (11). While the cortisol levels in the anesthetized transported fish declined significantly as compared to the control group. Moreover, the glucose levels elevated in the fish serum in both anesthetized groups with and without transportation as compared to the control group. These results go along with the results of Bahrekazemi et al. (29) and can be attributed to the side effects of MS-222 that cause hypoventilation and affected ATP/ $/ \mathrm{Na}^{+}-\mathrm{K}^{+}$ase activity so the glucose levels increased as well as the concentration of creatinine phosphate which are the product of carbohydrate metabolism used to supply energy (30). The results of this study reveal that there is no effect of MS-222 on liver cells shown as there is no significant variation in the level of ALT in fish serum in all groups. However, the creatinine phosphate activity declined in both anesthetized groups which contradict the results of Congleton (30) who reported increased activity of creatinine phosphate in the blood of chinook salmon. The variation of these results may be related to the genetics, type, and the age of fish or species, and the dose of MS-222 in addition to the physical and chemical characteristics of water.

The results of the present study exhibited no significance difference in hematological parameters in all groups, this pointed with other workers Wisteska et al. (31) who reported a presence of minor statistical variation in hematology characters in common carp. Moreover, Stockman et al. (32) observed no changes in PCV levels in Cyprinus carpio treated with MS-222 (50-190 mg/l). These may be due to stress hormone (cortisol), which does not vary from the control group. Consequently, it did not affect to initiate a secondary response to stress such as degeneration of protein, and disturbances in osmolality (chlorine, sodium and potassium and other ions inflation of RBC, and the breakdown of fat and glycogen) (33).

\section{Conclusion}

This study concluded that MS-222 induces rapid induction and recovery time and can reduce stressful conditions resulted from fish transportation.

\section{Acknowledgement}

The thanks the College of Veterinary Medicine, University of Mosul for supporting this research.

\section{Conflict of Interest}

No conflict interests

\section{References}

1- Balasch JC, Tort L. Netting responses in fish. Front Endocrinol. 2019;10:62. http://doi.org/10.3389/fendo.2019.00062
2- Li T, Brouwer M. Hypoxia-inducible factor, gsHIF, of the grass shrimp Palaemonetes pugio: Molecular characterization and response to hypoxia. Comp Biochem Physiol. 2007;147(B):11-19. http://doi.org/10.1016/j.cbpb.2006.12.018

3- Monirian J, Sutphin Z, Myricreatinine C. Effects of holding temperature and handling stress on the upper thermal tolerance of threadfin shad Dorosoma petenense. J Fish Biol. 2010;761329-1342. www.doi.org/10.1111/j.10958649.2010.02568.x

4- Ahmed KB, Shenoy. Effect of transportation stress on the humoral immunity of catla fry and fingerlings. J Acad Indust Res. 2012;401-403. [available here]

5- Portz DE, Woodley CM, Cech JR. Stress-associated impacts of shortterm holding on fishes. Rev Fish Biol Fish. 2006;16:125-170. http://doi.10.1007/s11160-006-9012-z

6- Carmichaelgj K, Tomasso JR. Survey of fish transportation equipment and techniques. Prog Fish-Culture.1988;50:155-159. https://doi.org/10.1577/15488640(1988)050<0155:CSOFTE $>2.3 . \mathrm{CO} ; 2$

7- Trushenski JT, Bowker JD, Cooke SJ, Erdahl D, Bell T, MacMillan JR, Yanong RP, Hill JE, Fabrizio MC, Garvey JE, Sharon S. Issues regarding the use of sedatives in fisheries and the need for immediaterelease options. Trans Am Fish Soci. 2013;142:156-170. http://doi.org/10.1080/00028487.2012.732651

8- Husen MA, Sharma S. Efficacy of anesthetics for reducing stress in fish during aquaculture practices- a review, Kathmandu Uni J Sci Eng Technol. 2014;10:104-123. [available here]

9- Daniel L. Available chemotherapy in Mediterranean fish farming: Use and needs and needs. In: Rogers C, Basurco B eds. Options mediterranean aquaculture. Zaragoza: Mediterranean Seminars; 2009. $1 \mathrm{p}$.

10- Meinelt T, Schulz C, Wirth M, Kürzinger H, Steinberg C. Dietary fatty acid composition influences the fertilization rate of zebrafish (Danio rerio Hamilton-Buchanon). J Appl Ichthyol.1999;15:19-23. https://doi.org/10.1046/j.1439-0426.1999.00121.x

11- Zahl IH, Kiessling A, Samuelsen OB, Hansen MK. Anaesthesia of Atlantic cod (Gadus morhua) - Effect of pre-anesthetic sedation, and importance of body weight, temperature, and stress. Aquacul. 2009;295:62-69. https://doi.org/10.1016/j.aquaculture.2009.06.019

12- Son MH, Park MW, Myeong JI, Kim DJ, Kim BH, Jo Q, Jeon IG. Anaesthetic Tolerance of Juvenile Black Rockfish Sebastess schlegeli, Produced for Wild Stock Enhancement. Ocean Polar Res. 2001;23:285290. [available at]

13- Tropic PN, Strunjak PI, Coz RJ, Barisic J, Jadan M, Berakvic PA. Tricaine methane-sulfonate (MS-222) application in fish anaesthesia. J Appl Ichthyol. 2012;28:553-564. http://doi.org/10.1111/j.14390426.2012.01950.x

14- Zahl IH, Samuelsen O, Kiessling A. Anaesthesia of farmed fish: implications for welfare. Fish physiology and biochemistry. 2012; 38(1), 201-218. https://doi.org/10.1007/s10695-011-9565-1. [available herel

15- Pirhonen J, Schrecreatinine CB. Effects of anesthesia with MS222, clove oil, and $\mathrm{CO} 2$ on feed intake and plasma cortisol in steelhead trout (Oncorhynchus mykiss). Aquacul. 2003;220:507-514. https://doi.org/10.1016/S0044-8486(02) 006 24-5

16- Lepic P, Stara A, Turek J, Kozak P, Velisek J. The effects of four anesthetics on hematological and blood biochemical profiles in vimba bream, Vimba vimba. Vet Med. 2014;59:81-87. http://doi.org/10.17221/7317-VETMED

17- Witeska M, Dudyk, J, Jarkiewicz, N. Hematological effects of 2phenoxyethanol and etomidate in carp (Cyprinus carpio L.). Vet Anaesth Analg. 2015;42:537-546. https://doi.org/10.1111/vaa.12242

18- Mayyahi M, AL-Jumaa Z, AL-Taee S, Nahi HH, AL-Hamdany MO, AL-Salih MA, Al-Mayahi B. Bioaccumulation of heavy metals and histopathological changes in muscles of common carp Cyprinus carpio L. in the Iraqi rivers. Iraqi J Vet Sci.2020;Xxxxxx,Xxxxxxxx DOI: 10.33899/ijvs.2020.126748.1368 (in press)

19- Husen AMD, Sharma S. Anesthetics Efficacy of MS-222, Benzoak ${ }^{\circledR}$ vet, AQUI-S ${ }^{\circledR}$, and clove oil on common carp (Cyprinus carpio) fry. Inter J Res Fish Aquacul. 2015; 5(3): 104-114. [available here] 
20- Burka JF, Hammell KL, Horsberg TE, Johnson, GR, Rainnie DJ, Speare DJ. Drugs in salmonid aquaculture: A review. J Vet Pharmacol Therap. 1997;20:333-349. http://doi.org/10.1046/j.13652885.1997.00094.x

21- Griffiths SP. The use of clove oil as an anesthetic and method for sampling intertidal rocreatinine phosphatepool fishes. J Fish Biol. 2000;57:1453-1464. http://doi.10.1111/j.10958649.2000.tb02224.x

22- Gabriel UU, Akinrotimi OA. Management of Stress in Fish for Sustainable Aquaculture Development. Researcher, 2011;3(4):28-38. Doi: www.doi.org/10.7537/marsrsj030411.05

23- Ismail RH, Al-Hamdani AH. Effect of Probiotic (Poultrystarß) and heat stress on some blood parameters in common carp (Cyprinus carpio L.). Iraqi J Vet Sci. 2019;33:221-225. DOI: www.doi.org/10.33899/ijvs.2019.125539.1061

24- Park IS, Park SJ, Gil HW, Nam YK, Kim DS. Anesthetic effects of clove oil and lidocaine- $\mathrm{HCl}$ on marine medaka, Oryzias dancena. Lab Anim. 2011;40:45-51. http://doi.org/10.1038/laban0211-45

25- Kiessling A, Johansson D, Zahl IH, Samuelsen OB. Pharmacokinetics, plasma cortisol, and effectiveness of benzocaine, MS-222, and isoeugenol measured in individual dorsal aorta-cannulated Atlantic salmon (Salmo salar) following bath administration. Aquacul. 2009;286:301-308. www.doi.org/10.1016/j.aquaculture.2008.09.037

26- Readman GD, Owen SF, Murrell JC, Knowles TG. Do fish perceive anesthetics as aversive? PLoS One. 2013;8:e73773. https://doi.org/10.1371/ journal. pone.0073773

27- Arnolds DEW, Zottoli SJ, Adams CE, Dineen SM, Fevrier S, Guo Y, Pascal AJ. Physiological effects of tricaine on the supramedullarydorsal neurons of the cunner, Tautogolabrus adspersus. Biol Bull. 2002;203:188-189. http://doi.org/10.2307/1543388

28- Crosby TC, Hill JE, Watson CA, Yanong RPE. Effects of tricaine methanesulfonate, Hypno, metomidate, quinaldine, and salt on plasma cortisol levels following acute stress in three spot gourami Trichogaster trichopterus. J Aqua Anim Hlth. 2006;18:58-63. http://doi.org/10.1577/H05-026.1

29- Bahrekazemi M, Yousefi N. Plasma enzymatic, biochemical, and hormonal responses to clove oil, 2-phenoxy ethanol, and MS-222 exposed to Caspian brown trout (Salmo trutta caspius, Kessler). Iranian J Aqua Anim Hlth. 2017;3(1):47-60. http://doi.org/10.18869/acadpub.ijaah.3.1.47

30- Congleton JL. Short communication, stability of some commonly measured blood - chemistry variables in juvenile salmonids exposed to a lethal dose of the anesthetic MS222. Aquacul Res. 2006;37:11461149. http://doi.org/10.1111/j.1365-2109.2006.01528.x

31- Wisteska M, Teodorczuk B, Lugowska K. Hematological effects of etomidate and tricaine in common carp. Turk $J$ Vet Anim Sci. 2017;41:93-98. http://doi.org/10.3906/vet-1603-30

32- Stoman J, Weber ESP, Kass PH, Pascoe PJ, Paul-Murphy J. Physiologic and biochemical measurement and response to noxious stimulation at various concentrations of MS-222 IN KOI (Cyprinus carpio). Vwt Anesth Analg. 2013;40:34-47. http://doi.org/10.1111/j.1467-2995.2012.00739.x

33- Ross LG, Ross B. Anesthetic and sedative techniques for aquatic animals. $3^{\text {rd }}$ ed. New York: Wiley publications; 2008. 222 p. http://doi.org/abs/10.1002/9781444302264

\section{الاستجابة السلوكية والكيموحيوية في اسماك الكارب والمعرضة للترايكائين ميثان سلفونيت كعقار مخدر الإني وتحت ظروف النقل}

شينباء خليل الطائي'، مي ذنون العناز'، منير سالم البداني' و الاء

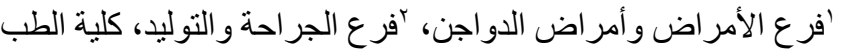

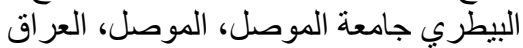

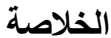

هدفت هذه الدر اسة لتحديد تأثثر الترايكائين ميثان سلفونيت وبتركيز

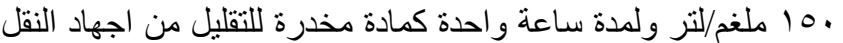

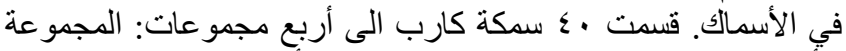

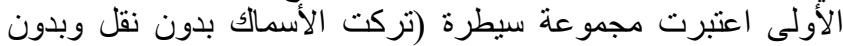

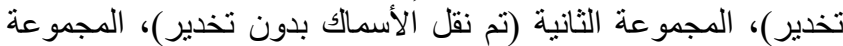

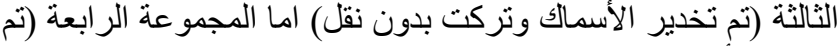

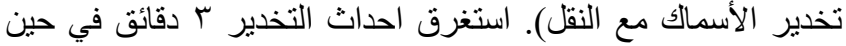

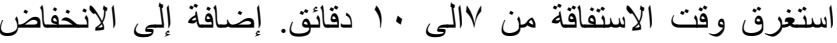

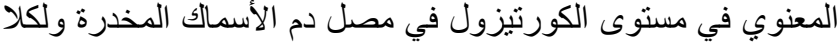

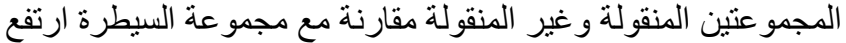

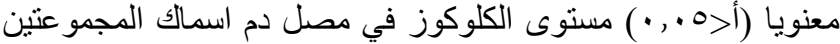

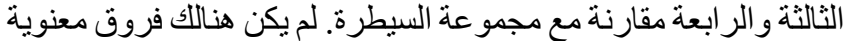

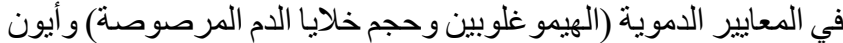
الصوديوم وكذلك في فعالية الإنزيمات و المتمثلة بالإنزيم الناقل للحامض فيل الأميني الالنين وفي كل المجموعات، في حين كاني كان مستوى الإنى أنزيم الكرياتينين فوسفيت منخفض معنويا في كلا المجمو عتين الثانية والثالثة

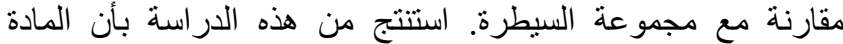
ترايكائين ميثان سلفونيت تستغرق وقت قصنير في استحداث التخدير و الاستفاقة و التقليل من إجهاد النقل في الأسماكل 